\title{
Tüketicinin Demografik Özellikleri Bağlamında Sosyal Sorumluluk Çalışmalarının Marka Tutumundaki Rolü
}

\author{
Nurhan Babür Tosun \\ profesör, marmara üniversitesi iletişim fakültesi
} nurhantosun@gmail.com

\section{Yelda Ülker}

araştırma görevlisi, marmara üniversitesi iletişim fakültesi yeldaulker@hotmail.com

\section{Abstract \\ The Role of Social Responsibility Activities on Brand Attitude in the Context of Demographic Characteristics of Consumers}

As a result of the rise in public awareness and technological developments, consumers have become more sensitive to the events in their surroundings. This sensitivity is reflected both on the consumer culture, and everyday life practices. In this context, consumers want their brands to be sensitive to the issues that are relevant to the society and they show a positive attitude towards the brands that show this sensitivity. In other words, brands are oriented towards social responsibility projects in order to gain awareness, to increase brand loyalty, to improve its image, and to strengthen brand values. In this study, it was aimed to determine the relationship between consumers' demographic characteristics and their attitudes towards brands that carried out social responsibility projects. To this end, a survey has been conducted with 435 consumers who shop at A101 markets on both sides of Istanbul. Questionnaires used in the study are based on attitude scales of Putrevu and Lord (1994), Peracchio and Meyers-Levi (1997). Thus, it has been examined whether there is a difference between consumers' demographic characteristics including their age, gender, marital status, educational status and active working life in their attitudes towards brands which perform social

Bu makaleye referans vermek için: Tosun B. N. ve Ülker Y., (2018). Tüketicinin Demografik Özellikleri Bağlamında Sosyal Sorumluluk Çalışmalarının Marka Tutumundaki Rolü. Galatasaray Üniversitesi Illeti-ş-im Dergisi, 28, 177-203. DOI: 10.16878/gsuilet.436043 
responsibility activities. According to the findings of the study, there is no significant relation between demographic characteristics including gender and being active in business life and their attitudes towards brands which performs social responsibility activities. However, there is a significant relation between their age, marital status and educational status and their attitudes towards brands which perform social responsibility projects.

keywords: social responsibility, brand attitude, consumer behaviour

\section{Résumé}

\section{Le rôle des activités de la responsabilité sociale sur l'attitude envers la marque dans le contexte des caractéristiques démographiques des consommateurs}

Avec la prise de conscience des consommateurs et le développement de la technologie, les consommateurs deviennent plus sensibles aux événements dans leur environnement. Cette sensibilité a des effets sur la culture de consommation ainsi que sur la vie quotidienne des gens. Dans ce contexte, les consommateurs veulent que les marques soient sensibles aux enjeux de la société et ont une attitude positive à l'égard des marques qui ont cette sensibilité. Par conséquent les marques sont orientées vers des projets de responsabilité sociale qui visent à augmenter la fidélité à la marque, améliorer son image et renforcer les valeurs de la marque. Dans cette étude, il s'agit de déterminer la relation entre les attitudes des consommateurs vis-à-vis de l'image de marque qui mènent des études de responsabilité sociale et leurs caractéristiques démographiques. Le questionnaire est basé sur le classement d'attitude de Putrevy et Lord (1994) et Peracchio et Meyers-Levi (1997). Dans le cadre de ce travail on a interrogé 435 personnes dans les A101 des deux côtés d'Istanbul. On a déduit qu'il existait une différence entre les caractéristiques démographiques des consommateurs, -notamment leur âge, leur sexe, leur statut matrimonial, leur niveau d'éducation et leur vie professionnelle active- et leurs attitudes envers les marques qui réalisent des études de responsabilité sociale. Selon les résultats de l'étude, il n'y a pas de corrélation entre le genre, la vie professionnelle consommateurs et les attitudes à l'égard des marques menant des projets de responsabilité sociale. Par contre leurs attitudes se diffèrent elon leur âge, leur statut matrimonial et leur statut éducatif, leurs attitudes envers la marque qui réalise le projet de responsabilité sociale.

mots-clés: responsabilité sociale, attitudes envers la marque, le comportement des consommateurs 


\section{Öz}

Insanların bilinçlenmesi teknolojinin gelişmesi ile tüketiciler, çevrelerinde olan olaylara karşı daha duyarlı davranmaktadır. Bu duyarlılı, insanların günlük yaşamını etkilediği gibi tüketim kültürüne de yansımaktadır. Bu bağlamda tüketiciler, kullandıkları markaların toplumu ilgilendiren konulara karşı duyarlı olmalarını istemekte ve bu hassasiyeti gösteren markalara karşı olumlu tutum sergilemektedir. Diğer bir deyişle markalar, sosyal sorumluluk projelerine yönelerek farkındalık kazanmak, marka sadakatini arttırmak, imajını geliştirmek ve marka değerlerini güçlendirmek istemektedir. Bu araştırmada, tüketicinin sosyal sorumluluk çalışması gerçekleştiren markalara yönelik tutumları ile demografik özellikleri arasındaki ilişkinin belirlenmesi amaçlanmıştır. Bu bağlamda, yapılan çalışmada, Putrevy ve Lord (1994) ile Peracchio ve Meyers-Levi (1997) tarafından oluşturulmuş tutum ölçeklerinden yararlanılıp, istanbul'un her iki kıtasındaki A101 marketlerini ziyaret eden 435 tüketiciye anket uygulanmıştır. Böylece tüketicilerin yaşları, cinsiyetleri, medeni durumları, eğitim durumları ve aktif iş yaşamlarını içeren demografik özellikleri ile sosyal sorumluluk çalışması yürüten markalara olan tutumları arasında fark olup olmadığı saptanmıştır. Çalışmanın bulgularına göre, tüketicilerin cinsiyet durumları ve aktif iş yaşamında olmaları ile sosyal sorumluluk projesi yürüten markalara yönelik tutumları arasında fark yoktur. Yaşları, medeni durumları ve eğitim durumları ile sosyal sorumluluk projesi yürüten markalara yönelik tutumları arasında ise fark vardır.

anahtar kelimeler: sosyal sorumluluk, marka tutumu, tüketici davranışı 


\section{Giriş}

Kurum ile tüketici arasındaki iletişimin anlamı konumunda olan marka, kişinin toplumda kendini görmek istediği yere ulaşmasını sağlamaktadır. Bu yaklaşıma göre marka, ait olduğu ürünü diğerlerinden simgesel özellikler yardımıyla farkıı kılar. Günümüz markalarının özdeşleşmek istediği temel simgesel anlamlardan biri toplumsal konulara karşı duyarlı olmaktır. Çünkü topluma yararlı olma görüşünün ivme kazandığı günümüzde tüketiciler, bu konuda markalara da sorumluluk yüklemektedir. Diğer bir deyişle, tüketici beklentileri doğrultusunda tutum sergileyen markaların kendilerine yönelik istedikleri tutumu oluşturmasının oldukça kolay olacağı yaklaşımı, markaların toplumsal konulara duyarlı olmasını zorunlu kılmaktadır. Nitekim çeşitli araştırmalar (Kotler ve Lee, 2013, s.11; Arendt ve Brettel, 2010, s.147; Herbert ve Schantz, 2007, s.109; Polonsky ve Jemons, 2006, s.341) markaların sosyal sorumluluk odaklı simgesel anlamlarının tüketici tutumunda etkili olduğunu göstermektedir.

Ait oldukları ürünlerin fiziksel varlığından daha çok soyut anlamları kapsayan markaların günümüzde kendilerine yüklemek istedikleri anlamların başında 'toplumsal konulara duyarlılık' gelmektedir. Diğer bir deyişle günümüzde markalar, ürünlerle değil, topluma kattıkları değerlerle ön plana çıkmak istemektedir (Yalur, 2014, s.17). Bu doğrultuda kurumların, çevreye, topluma, çalışanlarına ve tüketiciye karşı sorumlulukları olduğu söylenebilir (Dean, 2014, s.92). Bu sebeple markalar, rakiplerinden ayrışmak, tüketicinin duygularına hitap ederek imajlarını güçlendirmek için sosyal sorumluluk projelerine önem vermektedirler. Çünkü topluma faydalı olma çabasının önem kazandığı günümüzde tüketiciler, kendileri kadar, kurumların da sorumlulukları olduğunu düşünmektedir (Aydın, 2013, s.7). Bu bağlamda tüketiciler, markaların toplumun istek ve intiyaçlarına duyarlı olmasını, çevreyi korumasını ve toplumsal sorunlara çözüm önermesini (Özdemir, 2009, s.58), etik ve dürüst olmasını, insan haklarına saygıı davranmasını, sosyal intiyaçları karşılamasını beklemektedir (Dean, 2014, s.92; Srivastava, 2010, s.62). Bu konuda yapılan araştırmalar, sosyal sorumluluk çalışmalarının markalara anlam yükleme bağlamında yararlar sağladığını göstermektedir (Chernev ve Blair, 2015, s.1412-1415; Kotler ve Lee, 2013, s.11; Arendt ve Brettel, 2010, s.147; Çerik ve Özarslan, 2008, s.590; Herbert ve Schantz, 2007, s.10; Polonsky ve Jemons, 2006, s.341; Argüden, 2002, s.16). Bu araştırmalar, sosyal sorumluluk projelerinin özellikle pazara yeni giren markaların imajını güçlendirerek sadakat oluşumunu kolaylaştırdığını, markaya itibar kazandırdığını dolayısıyla da satın almayı gerçekleştirdiğini söylemektedir. Bu bağlamda markaların sosyal sorumluluk çalışmalarının tüketicilerin tutumlarını olumlu etkilediği sonucuna varılmaktadır.

Bu çalışmada, sosyal sorumluluk projesi yürüten markalara yönelik olarak tüketicide oluşan tutumun demografik özellikler bağlamında değişiklik gösterip göstermediğinin değerlendirilmesi amaçlanmıştır. Diğer bir deyişle, tüketicinin, sosyal sorumluluk projeleri gerçekleştiren markalara yönelik tutumları ile yaşları, cinsiyetleri, gelir durumları, medeni durumları, aktif iş yaşamları gibi demografik özellikleri arasındaki fark irdelenmektedir. 


\section{Sosyal Sorumluluk Kavramı}

Geçmişi oldukça eskilere dayanan sosyal sorumluluk kavramı sanayi devrimi ile birlikte çok önem kazanmıştır (Aktan ve Börü, 2007, s.22). Sanayi devrimi doğrultusunda gelişen otomasyon ve seri üretim, işletme kavramının önem kazanmasının yanı sıra işletmelerin ekonomi için önemli bir bileşen olmasına neden olmuştur. Bu dönemde işletmeler, kar odaklı çalışmak için sosyal sorumluluk çalışmalarına yönelme eğilimi içinde bulunmuşlardır (Kaşlı, 2011, s.10). Bu nedenle birçok yazar tarafından 1920'li yıllar, sosyal sorumluluk kavramının doğuşu olarak kabul edilmektedir (Aktan ve Börü, 2007, s.22). Büyük buhran döneminde ise şirketlerin sosyal sorumluluğa sahip olup olmadığıyla ilgili tartışmalar yaşanmış ve bu tartışmalar doğrultusunda kurumlara toplumun sorunlarına yönelmeleri için çeşitli baskılar uygulanmıştır (Aydın, 2013, s.12). Bu baskılarla birlikte, gelişen sanayileşmeyle çoğalan işçi sömürülmesi ve giderek artan fakirlik, İngiltere'deki bazı kuruluşların yardım faaliyetleri kapsamında örgütlenmesine neden olmuştur (İncesu, 2011, s.19). Özellikle 1960'lı yıllarda, birçok Amerikan şirketi toplumsal baskı görmüş ve bu doğrultuda kurumlar, sosyal sorumluluk projelerine önem vermeye başlamışlardır (Kotler ve Lee, 2013, s.7). 1960 'ı yıllardan sonra ise sosyal sorumluluk çalışmalarına yönelmede önemli bir artış görülmektedir. Günümüzde de özellikle 'Love Mark' haline gelmek isteyen markalar, sosyal sorumluluk projelerine ağırlık vermektedir. Örneğin, intiyacı olan çocuklara ayakkabı sağlamayı amaçlayan ve 'One for One' kampanyasıyla adından söz ettiren TOMS markası, satılan her çift ayakkabıya karşıık, ihtiyaç sahibi bir çocuğa ayakkabı temin etmektedir. Böylece satın aldıkları TOMS marka ayakkabı ile bir çocuğu ayakkabı sahibi ettirdiğini bilen tüketicinin projeye destek vermesi sağlanmaktadır (Gürak, 2017).

Frederick (1960) sosyal sorumluluk kavramını, işletmelerin sadece kendini değil, toplumun da çıkarlarını düşünerek kaynaklarını kullanması olarak açıklarken, Elkinton (1998), sosyal sorumluluğu finansal, çevresel ve sosyal zemin üzerinde değerlendirerek, bu üç unsurun dengeli bir şekilde aktif olarak çalışması gerektiğini savunmaktadır. Carroll $(1991$, s.4) ise sosyal sorumluluk kavramını, şirketlerin tüketicinin ihtiyaç duyduğu malı- hizmeti üretmesi ve satması yani ekonomik sorumlulukları ve bu ekonomik faaliyetleri icra ederken yerine getirmesi gereken yasal sorumlulukları, yasalarda yer almayan ama toplumun beklediği doğru davranış kalıpları yani ahlaki sorumlulukları ve içinde bulundukları sosyal çevreye yardım etmek amaçlı yaptığı gönüllü sorumluluklarından oluşturduğu dört boyutlu bir piramit ile açıklamaktadır. Wood'un (1991) sosyal sorumluluk kavramının tanımında toplumla işletmenin ayrı ayrı değil, bir bütün olma hali olduğunu söylemektedir. Yapılan geçmiş çalışmalara bakıldığında kurumların iç ve dış paydaşlarının en büyük taleplerinden biri olan sosyal sorumluluk projelerinin (Becan, 2011, s.26), markaların ve toplumun değer yargıları ile uyumlu olması gerektiğinin sıklıkla vurgulandığı görülmektedir (Kakabadse vd., 2005, s.279). 
Yukarıdaki tanımlar bağlamında genel olarak sosyal sorumluluk, şirketin sadece kendi çıkarları doğrultusunda hareket etmemesi ve toplumu ilgilendiren her türlü olaya duyarlı olup, gene toplumu olumlu yönde etkileyecek çalışmalara gönüllü olarak katkı sağlaması olarak nitelenebilir.

\section{Marka Tutumu Oluşumunda Sosyal Sorumluluğun Rolü}

Bir markanın toplumda kabul görmesi sadece toplumdaki sorunların farkında olmasına değil, bu sorunları çözmek için çaba sarf etmesine de bağlıdır (Yalur, 2014, s.19). Bu nedenle, toplumsal sorunlar odaklı projelerin giderek önem kazandığı günümüzde, markaların bu eğilimi göz ardı etmesi doğru değildir. Bu bağlamda sosyal sorumluluğa sahip olduklarını sergilemek isteyen markalar, geleneksel anlayıştan uzaklaşarak çevre dostu ürünler, ambalajlar kullanmaya ve içinde bulundukları toplumun çeşitli sorunlarına odaklanmaya yönelmektedir (Aydın 2013, s.10).

Marka kavramı ait olduğu ürünün fiziksel varlığından çok, hedef kitlede oluşan soyut anlamlara dayanmaktadır. Bu nedenle bir markanın başarılı olması için ulaşmayı amaçladığı kitlenin gereksinim duyduğu anlamlara seslenmesi zorunluluktur. Sosyal sorumluluk konularına duyarlıı̆ı artan bireylerin giderek artması diğer bir deyişle bu anlama gereksinim duyulması markaların bu konulara yoğunlaşmasının temel nedenidir. Bu bağlamda, günümüz markalarının sosyal sorumluluk konusuna odaklanma amaçlarının, kendilerine toplumsal sorunlara duyarlı olmak şeklinde simgesel anlam yükleyerek tutum oluşumunu sağlamak olduğu söylenebilir. Çünkü bir markaya yönelik olarak gerçekleştirilen simgesel çağrışımlar, tüketicilerde marka tutumu oluşmasına katkı sağlar. Keller'in (1993, s.4), tutum çağrışımları olarak adlandırdığı çağrışımlar, markanın tüketici beklentileri doğrultusunda tutum sergilemesini ifade etmektedir. Bu doğrultuda bir markanın sosyal sorumluluk konularını içeren simgesel çağrışım amacını, tutum çağrışımı oluşturma niyeti olarak değerlendirmek mümkündür. Bir nesnenin veya bireyin olumlu veya olumsuz olarak değerlendirilmesine tutum denilmektedir (Park vd., 2010, s.1). Bir başka deyişle, deneyimler, bilgiler, duygular biçim değiştirdikçe, buna bağlı olarak tutum da değişmektedir (İnceoğlu, 2011, s.23). Genel anlamıyla tutum, bireylerin bir 'şey' e ilişkin bilgileri, duyguları ve davranış eğilimlerinin bir bütünüdür. Markanın sahip olduğu işlevsel çağrışımlar bilişsellikte, simgesel çağrışımlar ise duygusallıkta oldukça önemlidir. İşlevsel ve simgesel çağrışımın kombinizasyonu ise davranışsal eğilimlerini kamçılar (Tosun, 2017, s.237-241). Tutum, tüketicinin marka tercihini ve satın alma davranışını yönlendirmenin yanı sıra imaj oluşumunu da gerçekleştirir (Jisana, 2014, s.37, Gibson, 2008, s.186). Diğer bir deyişle, tüketicilerin markaya ait bilişsel değerlendirmeleri, duygusal tepkileri ve davranış eğilimleri, mevcut tutumlarının ipuçlarını verir (Loken vd., 2002, s.149-161). Nesnel özelliklerin yerine simgesel özelliklerin vurgulanması tutum oluşumunu çabuklaştırır (Sujan ve Bettman,1990, s.54-67). Bu nedenle, markalar tüketicide olumlu duygu ve davranış yaratacağına inandıkları, sosyal sorumluluk projelerine yönelmektedir. Ancak bu noktada önemli olan kullanılan 
simgesel özelliklerin tüketici açısından önem taşımasıdır. Sosyal sorumlulukla ilgili konuların günümüzde tüketici açısından öneminin giderek artması markaların sosyal sorumluluk simgesini kullanmasının temel nedenidir.

Yukarıda belirtilen nedenlerden ötürü, sosyal sorumluluk projeleri aracılığıyla markaya karşı tüketicide oluşturulan olumlu tutumlar, satın alma davranışının ve sadakatin oluşmasını da sağlamaktadır (Elden, 2013, s.416). Diğer bir deyişle, sosyal sorumluluk projelerine yatırım yapan markalar, tüketicideki inanç, tutum ve davranışlarda değişiklikler yapmayı hedeflemektedir (Hoeffler vd., 2010, s. 78-88). Nitekim Lai ve arkadaşlarının (2010) yapmış olduğu bir araştırma sosyal sorumluluk projelerinin markaların denkliği ve performansı üzerinde olumlu etkisi olduğunu göstermektedir. Amerika'da yapılan bir araştırmaya göre, tüketiciler çevreye duyarlı, hayvanlar üzerinde denenmemiş yani etik kurallara uygun olarak üretilmiş ürünlere karşı olumlu duygu beslemekte ve o markaya daha fazla rağbet etmektedir (Lembet, 2012, s.22). Günümüzde tüketiciler, satın aldıkları markanın toplum için ne yaptığına bakıp ona göre satın alma niyeti göstermektedir (Yalur, 2014, s.20). Bu nedenle sosyal sorumluluk projelerini destekleyen markalar, imajlarını sağlamlaştırıp, rakiplerinden ayrılabilmekte ve tüketicideki sadakat duygusu oluşturabilmektedir. Business and Sustainable Development'ın 2006 yılında yaptığı bir araştırmaya göre Amerika'daki tüketicilerin \%43'ü, Avrupa'dakilerin \%20'si ile Asya'da \%8'inin markaların yürüttüğü sosyal sorumluluk projesi doğrultusunda, markayı değiştirebilmektedir (Polonsky ve Jevons, 2006, s.341). Uslu ve arkadaşlarının (2008) yapmış olduğu çalışmada da, tüketicilerin sosyal sorumluluk kampanyalarına yönelik pozitif bir tutum sergiledikleri belirlenmiştir. Uslu'nun çalışmasına göre sosyal sorumluluk projesine sahip markalara karşı tüketiciler olumlu bir tutum sergilemektedir. Bu çalışmanın yanı sıra, Onaran vd. (2013) de sosyal sorumluluk kampanyalarının tüketici algılamalarını ölçmeye yönelik çalışmalarında benzer sonuçlar elde etmiştir. Çalışmaya göre, kurumlar müşteri kazanmak ve imajlarını güçlendirmek için sosyal sorumluluk faaliyetleri gerçekleştirmekte ve tüketiciler tarafından bu çalışmaları desteklenmektedir. Nitekim sosyal sorumluluk ile ilgili çalışmalarda, tüketicilerin, kurumların sosyal davranışları ile ilgilendiği ve bu davranışın satın alma kararlarını etkilediği vurgulanmaktadır (Castaldo vd., 2009, s.1). Diğer bir deyişle, kurumların sosyal sorumluluk projelerinde yer alması, tüketicinin satın alma davranışını da etkilemektedir. Bu bağlamda America Express'in Özgürlük Anıtını yenileme kampanyası örnek verilebilir. Kampanyaya göre, kart sahiplerinin kartı her kullanışında belli bir miktar, şirketin Özgürlük Anıtını yenileme fonuna gitmektedir. Kampanya sayesinde anıtın yenilenmesi için 1,8 milyon dolar toplanmıştır. Ayrıca kart kullanımlarında \%27'lik ve kart üyeliği başvurularında da \%10'luk bir artış olmuştur (Kotler ve Lee, 2013, s.13).

Lii ve Lee'nin 2012 yılında yapmış olduğu araştırmada, kurumların hayırseverlilik ve sponsorluk faaliyetlerinin tüketicilerin tutumlarına etkisi araştırımış ve bu amaçla Putrevu ve Lord'un (1994) ölçeğinden faydalanmıştır. Çalışmada, tüketicilerin yardım amaçlı sosyal sorumluluk projesi yürüten markaları 
daha olumlu değerlendirdiği bilgisine ulaşılmıştır. Bu bilgiler doğrultusunda sosyal sorumluluk projesi yürüten markalara karşı tüketicinin tutumunun, bu tür projeler yapmayan markalara oranla daha olumlu söylenebilir. Ancak yapılan çalışmalar, tüketicilerin demografik özellikleri bağlamında, sosyal sorumluluk çalışması yapan markalara olan tutumların farkııık gösterdiğini vurgulamaktadır. Diğer bir deyişle cinsiyet, yaş, ekonomik durum, medeni durum ve iş yaşamı gibi demografik özellikler, tüketicinin markaya olan tutumunu etkilemektedir (Wu, 2003, s.37-44). Örneğin, erkeklerle karşılaştırıldığında, kadınlar daha çok satın alma faaliyetlerinde bulunmaktadır (Slama ve Tashlian, 1985). Bunun yanı sıra kadınların satın alma davranışları, erkeklere oranla mağaza personelinin davranışlarından daha çok etkilenmektedir (Gilber ve Warren, 1995). Sadece satış personelinin davranışı değil, markanın çevresel konulara olan duyarılıı̆ı da kadınların satın alma davranışını etkilemektedir. Mainieri ve arkadaşlarının (1997, s.202) ile Straughan ve Roberts'in (1999, s.560) yapmış olduğu çalışmalarda da kadınların çevre konularına erkeklerden daha duyarlı olduğu ve satın alma davranışı sergilerken çevresel konuları göz önünde bulunduran markalara öncelik verdikleri sonucuna varılmıştır. Bu bağlamda, kadınların sosyal sorumluluk projesi yürüten markaları tercih ettikleri söylenebilir. Wu ve Wang'ın (2014) yapmış olduğu çalışmada ise, $X$ ve $Y$ kuşaklarının sosyal sorumluluk projeleri yürüten markalara karşı birbirlerinden farklı tutumlar sergiledikleri saptanmıştır. Çalışmaya göre, çevresel sosyal sorumluluk projeleri yürüten markalara karşı gelecekte satın alma davranışı oluşması olasılığı X kuşağında daha yüksektir. Bu bağlamda, marka yöneticileri açısından, tüketicide tutum oluşturma veya var olan tutumu değiştirme çalışmalarında tüketicinin demografik özellikleri üzerinde dikkatle durulması gereken bir konudur..

Prado-Lorenzo vd.'nın (2008), Maignan'ın (2001), Quazi ve OBrien'in (2000) yapmış olduğu araştırmalarda da farklı kültürlere sahip toplumların sosyal sorumluluk çalışmalarına karşı farkı tutumlar sergilendikleri ortaya çıkmıştır. Bu doğrultuda, farklı özelliklere sahip tüketicinin sosyal sorumluluk projesi yürüten markalara karşı farklı tutumlar sergiledikleri söylenebilir. Burada önemli olan tüketicinin, markanın yürüttügü sosyal sorumluluk projesinin bilincinde olmasıdır (Wesley vd., 2012). Tüketici markanın sosyal sorumluluk projesinden ne kadar çok farkında olursa, o kadar çok tutumuna yansıtabilir. Diğer bir deyişle, sosyal sorumluluk projesi ile marka, tüketicinin zihninde olumlu bir imaj yaratabilmekte (Alexanderid 2014; Becker-Olsen vd., 2006), böylece toplumsal sorumluluğu üstlenen marka, iyi bir imaja ve üne sahip olabilmektedir (Giannarakis ve Theotokas, 2011). Tüketicinin zihnini olumlu yönde etkilemek amacıyla sosyal sorumluluk faaliyetlerine başlayan markaların, tüketicinin tutumlarını da olumlu yönde etkilediği kabul edilmektedir (Huynh ve Friberg, 2014, s.14).

Bir kurumun sosyal sorumluluk projelerini desteklemesi, o kurumun çalışanlarını da olumlu yönde etkiler. Yapılan araştırmalara göre, toplumsal katkıları olan kurumlarda çalışan personel, kurumuna daha bağlı olup, toplumun sorunlarına çözüm arayan bu kurumlara kendilerini daha yakın hissetmektedirler. 
Ayrıca sosyal sorumluluk projelerinde görev alan çalışanlar, bilgi ve becerilerini geliştirmenin yanı sıra kendilerine olan güvenlerini de arttırmakta ve sorun çözme becerilerine sahip kişiler haline gelmektedirler (Yalur, 2014, s.20-22). Sosyal sorumluluğun katkısını bilen Sabancı, Koç, Turkcell, Arçelik gibi önemli kurumlar toplum yararına yapılan çalışmalarla ön plana çıkıp, imajlarını geliştirmekte (Özdemir, 2009, s.68) ve çalışanları da sosyal sorumluluk projelerinde gönüllü olarak yer almaktadır. Böylece çalışanlar arasındaki iletişim ve güven duygusu da artarak takım ruhu oluşmaktadır. Bu durum çalışanın performansına da katkı sağlamaktadır (Sönmez, 2014, s.17). Kurumlar bu nedenle çalışanlarının sosyal sorumluluk projelerinde görev almaları için çaba sarf etmektedirler. Örneğin IBM markası, çalışanlarını okullardaki gençlere yol göstermeleri için desteklemektedir (Kotler ve Lee, 2013, s.172). Bu bağlamda çalıştıkları kurumların sosyal sorumluluk projelerinde yer alan çalışanların, birlik içinde beraber daha rahat çalıştığı, katııım duygusunu yoğun hissettikleri ve daha çok paylaşımda bulundukları görülmektedir (Kim ve Scullion, 2013, s.14-16). Özgüven'in (2013) yapmış olduğu çalışmaya göre de sosyal sorumluluk kampanyalarına karşı olan tutum, güven ve kurum imajını arttırdığı için markaya olan bağıı̆ı̆ı da güçlendirmektedir. Ayrıca, sosyal sorumluluk projeleri aracılığıyla kurumlar farklı pazarlarda tanınmakta ve hızla yayılmaktadır (Kaşlı, 2011, s.29). Bu doğrultuda yeni pazarlara girerken, müşteri bağ|ıığını sağlamada da sosyal sorumluluk önem taşımaktadır (Özgüven, 2010, s.26). Çünkü günümüzde tüketiciler satın aldıkları ürünün arkasında kimin olduğunu ve ne tür sosyal sorumluluk projeleri yaptıklarını bilmek istemektedirler (Özdemir, 2009, s.64).

\section{Araştırmanın Amacı ve Hipotezleri}

Sosyal sorumlulukla ilgili konuların günümüzde tüketici açısından öneminin giderek artması diğer bir deyişle tüketicilerin, markaların toplumsal sorunlara duyarlııı göstermesi beklentisi içinde olması nedeniyle markalar tutum oluşturmak amacıyla sosyal sorumluluk çalışmalarına yönelmektedir. Yapılan araştırmalar günümüz tüketicisinin çevre sorunları, insan ve hayvan hakları gibi konulardaki duyarlıığının arttığını göstermektedir (Alnıaçık, 2009, s.49). Bu doğrultuda tüketici, sahip olduğu duyarlıı̆ın aynısını kullandığı markanın da göstermesini istemektedir. Diğer bir deyişle kişilerin, bir markaya karşı oluşan tutumlarında, o markanın toplumsal konulara olan duyarlılı̆ının etkili olduğu söylenebilir. Bu çalışmada, tüketicinin demografik özelliklerinin, sosyal sorumluluk projeleri yürüten markalara yönelik tutumlarındaki rolü irdelenmektedir. Bu bağlamda, araştırmada tüketicinin, sosyal sorumluluk projeleri gerçekleştiren markalara yönelik tutumları ile yaşları, cinsiyetleri, gelir durumları, medeni durumları gibi demografik özellikleri arasındaki farkın belirlenmesi amaçlanmıştır. Diğer bir değişle, tüketicinin sosyal sorumluluk projesine sahip markalara ilişkin tutumlarının demografik özellikler bağlamında değişiklik gösterip göstermediğinin saptanması bu araştırmanın temel amacını oluşturmaktadır. 
Araştırmada, Kotler ve Lee (2013) ile Carroll (1991)'in çalışmalarına dayanılarak aşağıdaki hipotezler geliştirilmiştir.

H1: Sosyal sorumluluk projelerinin marka tutumu üzerindeki rolü ile tüketicilerin cinsiyeti arasında fark vardır.

H2: Sosyal sorumluluk projelerinin marka tutumu üzerindeki rolü ile tüketicilerin yaşı arasında fark vardır.

H3: Sosyal sorumluluk projelerinin marka tutumu üzerindeki rolü ile tüketicilerin eğitim durumu arasında fark vardır.

H4: Sosyal sorumluluk projelerinin marka tutumu üzerindeki rolü ile tüketicilerin medeni durumu arasında fark vardır.

H5: Sosyal sorumluluk projelerinin marka tutumu üzerindeki rolü ile tüketicilerin aktif iş hayatında yer alması arasında fark vardır.

H6: Sosyal sorumluluk projelerinin marka tutumu üzerindeki rolü ile tüketicilerin gelir durumu arasında fark vardır.

\section{Araştırma Metodolojisi}

Araştırmalarda veri toplamak için, bilgi ve verilerin en kolay toplanabildiği kolayda örnekleme yöntemi (Kurtuluş, 2010, s.63) kullanılmıştır. Pazarlama araştırmalarında 'problem çözümüne yönelik yapılan araştırmalar' da tipik örnek hacminin 300 ile 500 arasında olması gerekmektedir (Gegez, 2007, s.259). Bu sebeple, Tüketicinin artık büyük mağazalar yerine BIM, A101, Şok gibi evlerinin yakınlarında bulunan küçük mağaza zincirlerinden alışveriş yapmak istediği dikkate alınmış (Laleli, 2015) ve araştırma Türkiye'de 2016 yılında en çok mağaza sayısına sahip olan A101 marketler zincirinde ('Zincir Marketlerin...', http://www. ortakalan.com.tr/....) yapılmıştır. Çalışmanın ana kütlesini kadın ve erkek tüketiciler oluşturmaktadır. Araştırma, zaman ve mali kısıtlarından dolayı sadece İstanbul ili ile sınırlı kalmıştır. Bu nedenle araştırma sonuçlarının Türkiye'ye genellenmesi gibi bir durum söz konusu değildir. Bu doğrultuda, Anadolu ve Avrupa yakasında bulunan iki tane A101 marketi seçilmiş ve araştırmada bu marketleri ziyaret eden tüketicilerden elde edilen veriler analiz edilmiştir. Çalışmada, A101 marketler zincirini ziyaret eden 500 tüketiciye yüz yüze anket uygulanmıştır. Yapılan anketlerden güvenilir bulunmayanlar elenmiş ve 435 kişilik bir örneklem miktarına ulaşılmıştır.

Araştırmada veri toplama amacıyla kullanılan anket formu iki bölümden oluşmaktadır. Anket formunun ilk bölümünde katıııcıların demografik özelliklerine ve değerlendirmeleri üzerinde etkili olabilecek çeşitli unsurlara ilişkin sorular bulunmaktadır. İkinci bölümde ise tüketicilerin sosyal sorumluluk çalışmalarında bulunan markalara olan tutumlarını ölçmeye yönelik sorular yer almaktadır. Araştırmada, katıımcıların sosyal sorumluluk projesi yürüten markalara yönelik tutumlarını ölçmek için Putrevy ve Lord (1994) ile Peracchio ve MeyersLevi (1997) tarafından oluşturulmuş tutum ölçeklerinden yararlanılmıştır. Böylece tüketicilerin yaşları, cinsiyetleri, medeni durumları gibi demografik özellikleri ile 
sosyal sorumluluk faaliyetlerine sahip markalara olan tutumları arasında fark olup olmadığı belirlenmiştir. Buna göre katıımcı ölçekte yer alan her bir ifadenin ilgili kategori için uygunluğunu 5'li skala üzerinden değerlendirmektedir.

Araştırmada Sosyal Sorumluluk Projelerinin Markaya Yönelik Tutum Ölçeğinin Güvenirlilik Analizi

"Sosyal Sorumluluk Projesi Geliştiren Markalara Yönelik Tutum" ölçeğinin güvenirliğini hesaplamak için iç tutarlılık katsayısı olan "Cronbach Alpha" hesaplanmıştır. Ölçeğin genel güvenirliği alpha=0.939 olarak çok yüksek bulunmuştur. Ölçeğin yapı geçerliliğinin ortaya koymak için faktör analizi yöntemi uygulanmıştır. Yapılan Barlett testi sonucunda $(p=0.000<0.05)$ faktör analizine alınan değişkenler arasında ilişkinin olduğu tespit edilmiştir. Yapılan test sonucunda $(\mathrm{KMO}=0.903>0,60)$ örnek büyüklüğünün faktör analizi uygulanması için yeterli olduğu tespit edilmiştir. Faktör analizi sonucunda değişkenler toplam açıklanan varyansı \%62.278 olan 4 faktör altında toplanmıştır. Güvenirliğine ilişkin bulunan alpha ve açıklanan varyans değerine göre "Sosyal Sorumluluk Projelerinin Markaya Yönelik Tutum" ölçeğinin geçerli ve güvenilir bir araç olduğu anlaşılmıştır. Ölçeğe ait oluşan faktör yapısı aşağıda görülmektedir.

Tablo 1. Sosyal Sorumluluk Projelerinin Markaya Yönelik Tutum Ölçeğinin Faktör Analizi

\begin{tabular}{|c|c|c|c|c|}
\hline Boyut & Madde & $\begin{array}{l}\text { Faktör } \\
\text { Yükü }\end{array}$ & $\begin{array}{l}\text { Açıklanan } \\
\text { Varyans }\end{array}$ & $\begin{array}{l}\text { Cronbach's } \\
\text { Alpha }\end{array}$ \\
\hline \multirow{7}{*}{ 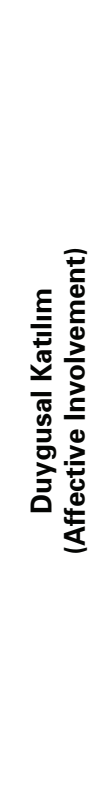 } & $\begin{array}{l}\text { Sosyal sorumluluk kampanyasına destek olan } \\
\text { markalar, dikkatimi çeker. }\end{array}$ & 0,898 & \multirow[t]{7}{*}{45,791} & \multirow[t]{7}{*}{0,936} \\
\hline & $\begin{array}{l}\text { Bir markanın sosyal sorumluluk projesi } \\
\text { yürütmesi, o markayı için tercih etmemde } \\
\text { etkilidir. }\end{array}$ & 0,845 & & \\
\hline & $\begin{array}{l}\text { Eğitim, spor ve çevre ile ilgili sosyal } \\
\text { sorumluluk kampanyaları yürüten markalara } \\
\text { karşı olumlu bir duygu beslerim. }\end{array}$ & 0,820 & & \\
\hline & $\begin{array}{l}\text { Markaların sosyal sorumluluk projelerine } \\
\text { destek vermesi markayı sevmemde etkilidir }\end{array}$ & 0,800 & & \\
\hline & $\begin{array}{l}\text { Markanın sosyal sorumluluk kampanyasına } \\
\text { sahip olması ürün/hizmeti hatırlamama } \\
\text { yardımcı olur. }\end{array}$ & 0,715 & & \\
\hline & $\begin{array}{l}\text { Sosyal sorumluluk projelerine destek veren } \\
\text { markaları daha kolay hatırlarım. }\end{array}$ & 0,649 & & \\
\hline & $\begin{array}{l}\text { Markaların sosyal sorumluluk projelerine } \\
\text { destek vermesi markaya olan güvenimin } \\
\text { oluşmasına yardımcı olur. }\end{array}$ & 0,582 & & \\
\hline
\end{tabular}




\begin{tabular}{|c|c|c|c|c|}
\hline \multirow{5}{*}{ 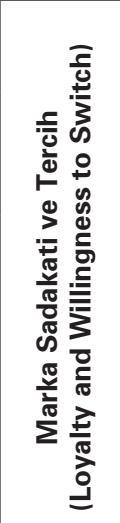 } & $\begin{array}{l}\text { Alışverişlerimde genellikle çevreye zarar } \\
\text { vermeyen markaları tercih ederim. }\end{array}$ & 0,812 & \multirow[t]{5}{*}{9,247} & \multirow[t]{5}{*}{0,938} \\
\hline & $\begin{array}{l}\text { Kullandığım markanın çevreye zarar verdiğini } \\
\text { öğrenirsem o markayı satın almayı bırakııım. }\end{array}$ & 0,806 & & \\
\hline & $\begin{array}{l}\text { Markanın çevre dostu olması o markayı } \\
\text { kullanmamda etkilidir. }\end{array}$ & 0,662 & & \\
\hline & $\begin{array}{l}\text { Sosyal sorumluluk kampanyası yürüten bir } \\
\text { markayı satın aldığımda, kampanyaya destek } \\
\text { verdiğim için mutlu olurum. }\end{array}$ & 0,551 & & \\
\hline & $\begin{array}{l}\text { Önem verdiğim bir sosyal amacı desteklemek } \\
\text { için marka tercihimi değiştirebilirim. }\end{array}$ & 0,439 & & \\
\hline \multirow{4}{*}{ 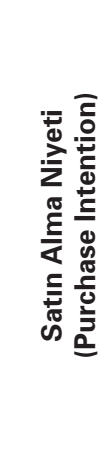 } & $\begin{array}{l}\text { Markanın sosyal sorumluluk projelerine } \\
\text { destek vermesi fiyatından daha önemlidir. }\end{array}$ & 0,820 & \multirow[t]{4}{*}{7,49} & \multirow[t]{4}{*}{0,938} \\
\hline & $\begin{array}{l}\text { Sosyal sorumluluk projesine sahip markaların } \\
\text { fiyatları artsa bile satın almaya devam ederim. }\end{array}$ & 0,817 & & \\
\hline & $\begin{array}{l}\text { Marka, sosyal sorumluluklarını yerine } \\
\text { getirmediğini düşünüyorsam başka bir marka } \\
\text { ile değiştirebilirim. }\end{array}$ & 0,626 & & \\
\hline & $\begin{array}{l}\text { Markanın sosyal sorumluluk projesi yürütmesi } \\
\text { o markayı satın almamı sağlar. }\end{array}$ & 0,431 & & \\
\hline \multirow{3}{*}{ 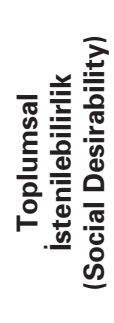 } & $\begin{array}{l}\text { Yeni bir ürünün/markanın tanıım reklamında } \\
\text { sosyal sorumluluk projesinin kullanıması beni } \\
\text { etkiler. }\end{array}$ & 0,694 & \multirow[t]{3}{*}{4,75} & \multirow[t]{3}{*}{0,936} \\
\hline & $\begin{array}{l}\text { Markanın sosyal sorumluluk kampanyası } \\
\text { yürütmesini samimi buluyorum. }\end{array}$ & 0,625 & & \\
\hline & $\begin{array}{l}\text { Sosyal sorumluluk kampanyası yürüten } \\
\text { markaları çevremdeki insanlara tavsiye } \\
\text { ederim. }\end{array}$ & 0,563 & & \\
\hline
\end{tabular}

"Sosyal Sorumluluk Projelerinin Markaya Yönelik Tutum" ölçeğinin faktör analizi değerlendirilmesinde özdeğeri birden büyük faktörlerin ele alınmasına, değişkenlerin faktör içerisindeki ağılığını gösteren faktör yüklerinin yüksek olmasına, aynı değişken için faktör yüklerinin birbirine yakın olmamasına dikkat edilmiş, yakınlığı yüksek olan ifadeler değerlendirmeye alınmamıştır. Ölçeği oluşturan faktörlerin güvenirlik katsayıları ve açıklanan varyans oranlarının yüksek olması ölçeğin güçlü bir faktör yapısına sahip olduğunu göstermiştir. Birinci faktörde yer alan maddeler "Duygusal Katılım" olarak ele alınmıştır. "Duygusal Katıım" faktörünü oluşturan 7 maddenin güvenirliği alpha= 0.936 olarak, açıklanan varyans değeri \%45.791 olarak saptanmıştır. İkinci faktörde yer alan 
maddeler "Marka Sadakati ve Tercih" olarak ele alınmıştır. "Marka Sadakati ve Tercih" faktörünü oluşturan 5 maddenin güvenirliği alpha= 0.938 olarak, açıklanan varyans değeri \%9.247 olarak saptanmıştır. Üçüncü faktörde yer alan maddeler "Satın Alma Niyeti"olarak ele alınmıştır. "Satın Alma Niyeti" faktörünü oluşturan 4 maddenin güvenirliği alpha= 0.938 olarak, açıklanan varyans değeri \%7.490 olarak saptanmıştır. Dördüncü faktörde yer alan maddeler "Toplumsal istenebilirlik" olarak ele alınmıştır. "Toplumsal Istenebilirlik" faktörünü oluşturan 3 maddenin güvenirliği alpha= 0.936 olarak, açıklanan varyans değeri $\% 4,750$ olarak saptanmıştır. Ölçekteki faktörlerin puanları hesaplanırken faktördeki maddelerin değerleri toplandıktan sonra madde sayısına bölünerek (aritmetik ortalama) faktör puanları elde edilmiştir.

Analizde Anova Testi yapılmıştır. Güvenirliğine ilişkin bulunan değerine göre "Sosyal Sorumluluk Projelerinin Markaya Yönelik Tutum" ölçeğinin geçerli ve güvenilir bir araç olduğu anlaşılmıştır.

Cronbach's Alpha Katsayısının değerlendirilmesinde kullanılan değerlendirme kriteri (Özdamar 2004);

$0,00 \leq \alpha<0,40$ ise ölçek güvenilir değildir.

$0,40 \leq \alpha<0,60$ ise ölçek düşük güvenilirliktedir.

$0,60 \leq \alpha<0,80$ ise ölçek oldukça güvenilirdir.

$0,80 \leq \alpha<1,00$ ise ölçek yüksek derecede güvenilir bir ölçektir.

Araştırmada Kullanılan Verilerin İstatistiksel Analizi

Araştırmada elde edilen veriler IBM SPSS (Statistical Package for Social Sciences) for Windows 22.0 programı kullanılarak analiz edilmiştir. Verileri değerlendirilirken tanımlayıcı istatistiksel metotları (Sayı, Yüzde, Ortalama, Standart sapma) kullanılmıştır.

Niceliksel verilerin karşılaştııımasında iki grup arasındaki farkı t-testi, ikiden fazla grup durumunda parametrelerin gruplar arası karşılaştırmalarında Tek yönlü (One way) Anova testi kullanılmıştır. Elde edilen bulgular \%95 güven aralığında $\% 5$ anlamlılık düzeyinde değerlendirilmiştir.

\section{Bulgular ve Değerlendirme}

Bu bölümde, araştırma probleminin çözümü için, araştırmaya katılan İstanbul'da yaşayan tüketicilerden ölçekler yoluyla toplanan verilerin analizi sonucunda elde edilen bulgular yer almaktadır.

\section{Demografik Veriler}

Aşağıdaki araştırmaya katılanların 225'i $(\% 51,7)$ erkek, 210'u $(\% 48,3)$ kadındır. Araştırmaya katılanlar yaş grubu değişkenine göre 114'ü $(\% 26,2) 15$ - 
20, 168'i $(\% 38,6)$ 21-26, 81'i $(\% 18,6)$ 27-32, 30'u (\%6,9) 33-38, 12'si $(\% 2,8)$, 39-40, 30'u $(\% 6,9) 46$ ve üstü olarak dağımaktadır. Katıımcıların eğitim durumu değişkenine göre 30'u (\%6,9), ilköğretim, 219'u $(\% 50,3)$ lise, 21'i $(\% 4,8)$ ön lisans, 78'i (\%17,9) lisans, 87'si $(\% 20,0)$ lisansüstü olarak dağılmaktadır. Ankete katılanların medeni durumu değişkenine göre 93'ü $(\% 21,4)$ evli, 342'si $(\% 78,6)$ bekar olarak dağılmaktadır. Katıımcıların çalışma durumu değişkenine göre 228 'i $(\% 52,4)$ çalışıyor, 207'si $(\% 47,6)$ çalışmıyor olarak dağılmaktadır. Ankete katılanların gelir durumu değişkenine göre 201'i (\% 46,2) 1000 TL'den az, 120'si (\%27,6) 1000-2999 TL, 87'si (\%20,0) 3000 - 4.999 TL, 27'si (\% 6,2) 5000 TL ve üzeri kazanıyor olarak dağılmaktadır.

\section{Sosyal Sorumluluk Projelerinin Markaya Yönelik Tutum Boyutunda Dağılım}

Araştırmaya katılan katılımcıların "Sosyal Sorumluluk Projesi Geliştiren Markalara Yönelik Tutumlarının" ölçüldüğü anket sorularına verilen cevaplar incelendiğinde;

"7- Bir markanın sosyal sorumluluk projesi yürütmesi, o markayı tercih etmemde etkilidir" ifadesine istanbul'da yaşayan katılımcıların, \%5,5'i ( $n=24)$ kesinlikle katılmıyorum, \% 13, 1'i (n=57) katımıyorum, \%20,7 ( $n=90)$ ne katılıyorum ne katılmıyorum, \%50,3'ü (n=219) katılıyorum, \%10,3'ü $(n=45)$ kesinlikle katılıyorum yanıtını vermiştir. Katılımcıların "bir markanın sosyal sorumluluk projesi yürütmesi, o markayı tercih etmemde etkilidir", ifadesine katıımın yüksek olduğu saptanmıştır. Bu sebeple katıııcıların yarısından çoğunun markaları tercih etmesinde sosyal sorumluluk projesi yürütmesini etkili olduğunu düşünebiliriz.

"8- Sosyal sorumluluk kampanyasına destek olan markalar, dikkatimi çeker." ifadesine İstanbul'da yaşayan katılımcıların, \%3,4'ü $(n=15)$ kesinlikle katılmıyorum, \%6,9'u ( $n=30)$ katılmıyorum, \%11,7'si ( $n=51)$ ne katılıyorum ne katılmıyorum, \%59,3'ü (n=258) katılıyorum, \% 18,6'sı ( $n=81)$ kesinlikle katılıyorum yanıtını vermiştir. Katıımcıların, "sosyal sorumluluk kampanyasına destek olan markalar, dikkatimi çeker." ifadesine yüksek düzeyde katıldıkları saptanmıştır. Bu veriden hareketle, sosyal sorumluluk kampanyasına destek olan markaların katıımcıların dikkatini daha kolay çektiğini söyleyebiliriz.

"9- Eğitim, spor ve çevre ile ilgili sosyal sorumluluk kampanyaları yürüten markalara karşı olumlu bir duygu beslerim." ifadesine katılımcıların, \%3,4'ü $(n=15)$ kesinlikle katımıyorum, \%7,6'sı ( $n=33)$ katımıyorum, \%11,7'si ( $n=51)$ ne katılıyorum ne katılmıyorum, \%55,2'si ( $n=240$ ) katılıyorum, \%22,1'i $(n=96)$ kesinlikle katılıyorum yanıtını vermiştir. Katılımcıların çoğunluğunun, eğitim, spor ve çevre ile ilgili sosyal sorumluluk projesi yürüten markaları sevdiği görülmüştür ve sosyal sorumluluk kampanyası yürüten markalara karşı pozitif tutumlarının oluşmasında etkili olduğunu düşünebiliriz. 
“10- Markaların sosyal sorumluluk projelerine destek vermesi markayı sevmemde etkilidir." ifadesine katılımcıların, \%4,8'i (n=21) kesinlikle katılmıyorum, \%11,7'si $(n=51)$ katılmıyorum, \%19,3'ü $(n=84)$ ne katılıyorum ne katılmıyorum, \%51,7'si (n=225) katılıyorum, \%12,4'ü $(n=54)$ kesinlikle katılıyorum yanıtını vermiştir. Ankete katılanların çoğunluğun markaların sosyal sorumluluk projesi yürütmesi sonucu markaya karşı olumlu duygulara sahip olduğunu söylenebiliriz.

“11- Markanın sosyal sorumluluk projesine destek vermesi fiyatından daha önemlidir." ifadesine katılımcıların, \%10,3'ü (n=45) kesinlikle katılmıyorum, \% 35,2'si ( $n=153$ ) katılmıyorum, \% 36,6'sı ( $n=159)$ ne katılıyorum ne katılmıyorum, \% 15,9'u (n=69) katılıyorum, \% 2,1'i $(n=9)$ kesinlikle katılıyorum yanıtını vermiştir. Katılımcıların çoğunun markanın sosyal sorumluluk projesine destek vermesini fiyatından daha önemli görmemektedir. Bununla birlikte ankete katılanların büyük bir çoğunluğunun kararsız kaldığını söyleyebiliriz.

“12- Yeni bir ürünün/markanın tanıtım reklamında sosyal sorumluluk projesinin kullanılması beni etkiler." ifadesine katılımcıların, \%4,1'i (n=18) kesinlikle katılmıyorum, \%17,2'si ( $n=75)$ katılmıyorum, \%24,8'i ( $n=108)$ ne katılıyorum ne katılmıyorum, \%44,8'i ( $n=195)$ katılıyorum, \%9,0'u (n=39) kesinlikle katılıyorum yanıtını vermiştir. İstanbul'daki katılımcıların çoğunluğu markaların reklamlarında sosyal sorumluluk projesi kullanmalarının kendilerini etkilediklerini düşündüklerini belirtmişlerdir.

“13- Markanın sosyal sorumluluk kampanyasına sahip olması ürün/hizmeti hatırlamama yardımcı olur." ifadesine katılımcıların, \%1,4'ü $(n=6)$ kesinlikle katılmıyorum, \%6,2'si ( $n=27)$ katılmıyorum, \%20,0'si ( $n=87)$ ne katılıyorum ne katılmıyorum, \%55,9'u (n=243) katılıyorum, \%16,6'sı $(n=72)$ kesinlikle katılıyorum yanıtını vermiştir. Katılımcıların çoğunluğunun sosyal sorumluluk kampanyası yürüten markaları hatırladıklarını söyleyebiliriz.

"14- Marka, sosyal sorumluluklarını yerine getirmediğini düşünüyorsam başka bir marka ile değiştirebilirim." ifadesine katılımcıların, \%9,0'u (n=39) kesinlikle katılmıyorum, \%21,4'ü (n=93) katılmıyorum, \%32,4'ü ( $n=141)$ ne katılıyorum ne katımıyorum, \%29,7'si ( $n=129)$ katılıyorum, \%7,6'sı (n=33) kesinlikle katılıyorum yanıtını vermiştir.

"15- Sosyal sorumluluk kampanyası yürüten markaları çevremdeki insanlara tavsiye ederim." ifadesine katılımcıların, \%4,8'i (n=21) kesinlikle katılmıyorum, \%15,2'si ( $n=66)$ katılmıyorum, \%29,0'u ( $n=126)$ ne katılıyorum ne katılmıyorum, \%42,8'i ( $n=186)$ katılıyorum, \%8,3'ü ( $n=36)$ kesinlikle katılıyorum yanıtını vermiştir. Ankete katılan katılımcıların çoğunluğu sosyal sorumluluk kampanyası yürüten markaları sevdiklerini ve çevresindekilere de kullanmaları için teşvik ettiklerini söyleyebiliriz. 
"16- Markanın çevre dostu olması o markayı kullanmamda etkilidir." ifadesine katılımcıların, \%2,8'i ( $n=12)$ kesinlikle katılmıyorum, \%7,6'sı ( $n=33$ ) katılmıyorum, \%13,1'i ( $n=57)$ ne katılıyorum ne katılmıyorum, \%44,1'i ( $n=192)$ katılıyorum, \%32,4'ü (n=141) kesinlikle katılıyorum yanıtını vermiştir. Ankete katılanların vermiş oldukları cevaplara bakıldığında büyük bir çoğunluğu markanın çevreye zarar vermemesini istediğini söyleyebiliriz.

"17- Sosyal sorumluluk projelerine destek veren markaları daha kolay hatırlarım." ifadesine katılımcıların, \%2,8'i (n=12) kesinlikle katılmıyorum, \%5,5'i $(n=24)$ katılmıyorum, \%22,1'i (n=96) ne katılıyorum ne katılmıyorum, \%54,5'i $(n=237)$ katılıyorum, \%15,2'si $(n=66)$ kesinlikle katılıyorum yanıtını vermiştir. Katılımcıların çoğunun sosyal sorumluluk projesi yapan markaları daha kolay hatırladığını söyleyebiliriz.

"18- Markanın sosyal sorumluluk projesi yürütmesi o markayı satın almamı sağlar." ifadesine katılımcıların, \%4,1'i (n=18) kesinlikle katılmıyorum, \%15,2'si ( $n=66)$ katılmıyorum, \%33,1'i $(n=144)$ ne katılıyorum ne katılmıyorum, \%44,1'i $(n=192)$ katılıyorum, \%3,4'ü $(n=15)$ kesinlikle katılıyorum yanıtını vermiştir.

"19- Marka, sosyal sorumluluk projesine sahip olması o markaya karşı ilgi duymama sebep olur." ifadesine katılımcıların, \%1,4'ü $(n=6)$ kesinlikle katılmıyorum, \%9,04'ü ( $n=39)$ katılmıyorum, \% 22,1'i (n=96) ne katılıyorum ne katılmıyorum, \%58,6'sı (n=255) katılıyorum, \%9,0'u (n=39) kesinlikle katılıyorum yanıtını vermiştir. Katılımcıların çoğunluğunun sosyal sorumluluk projesi yapan markalara karşı olumlu tutuma sahip olduğunu söyleyebiliriz.

"20- Alışverişlerimde genellikle çevreye zarar vermeyen markaları tercih ederim." ifadesine İstanbul'da yaşayan katılımcıların, \%2,1'i (n=9) kesinlikle katılmıyorum, \%5,5'i ( $n=24)$ katılmıyorum, \% 24,8'i $(n=108)$ ne katılıyorum ne katılmıyorum, \% 44,1'i (n=192) katılıyorum, \% 23,4'ü $(n=102)$ kesinlikle katılıyorum yanıtını vermiştir. Katılımcıların çoğunluğunun marka seçiminde, çevre dostu olanları tercih ettikleri görülmektedir.

"21- Sosyal sorumluluk projesine sahip markaların fiyatları artsa bile satın almaya devam ederim." ifadesine İstanbul'da yaşayan katılımcıların, \%13,8'i $(n=60)$ kesinlikle katılmıyorum, \%40,0'ı ( $n=174)$ katılmıyorum, \%28,3'ü ( $n=123)$ ne katılıyorum ne katılmıyorum, \%15,2'ü ( $n=66)$ katılıyorum, \% 2,8'i $(n=12)$ kesinlikle katılıyorum yanıtını vermiştir. Katılımcıların "sosyal sorumluluk projesine sahip markaların fiyatları artsa bile satın almaya devam ederim. " ifadesine katılımın az olduğu saptanmıştır. Bu sebeple katılımcıların çoğunluğunun markaları tercih ederken, ürünün fiyatını göz önünde bulundurduğu saptanmıştır.

“22- Markaların sosyal sorumluluk projelerine destek vermesi markaya olan güvenimin oluşmasına yardımcı olur." ifadesine İstanbul'da yaşayan katılımcıların, \%2,8'i (n=12) kesinlikle katılmıyorum, \%9,7'si $(n=42)$ katılmıyorum, \%24,1'i 
( $n=105)$ ne katılıyorum ne katılmıyorum, \%56,6'sı ( $n=246)$ katılıyorum, \% 6,9'u $(n=30)$ kesinlikle katılıyorum yanııını vermiştir. Katılımcıların, "markaların sosyal sorumluluk projelerine destek vermesi markaya olan güvenimin oluşmasına yardımcı olur." ifadesine yüksek düzeyde katıldıları saptanmıştır. Ankete katılanların sosyal sorumluluk projesi yürüten markalara daha çok güvendiğini söyleyebiliriz.

"23- Markaların sosyal sorumluluk projelerine destek olması önemlidir." ifadesine katılımcıların, \%0,7'si $(n=3)$ kesinlikle katılmıyorum, \%4,8'i ( $n=21)$ katımıyorum, \%10,3'ü ( $n=45)$ ne katılıyorum ne katılmıyorum, \%59,3'ü ( $n=258)$ katıııorum, \%24,8'i (n=108) kesinlikle katılıyorum yanıtını vermiştir. Katıımcıların çoğunluğu için, markaların sosyal sorumluluk projesi yürütmesi önemlidir.

"24- Çevreye ve topluma destek vermeyen markaları satın almam" ifadesine İstanbul'da yaşayan katılımcıların, \% 4,8'i $(n=21)$ kesinlikle katılmıyorum, $\% 26,2$ 'si $(n=114)$ katılmıyorum, \%33,8'i $(n=147)$ ne katılıyorum ne katılmıyorum, \%26,2'si ( $n=114)$ katılıyorum, \%9,0'u ( $n=39)$ kesinlikle katılıyorum yanıtını vermiştir.

"25- Önem verdiğim bir sosyal amacı desteklemek için marka tercihimi değiştirebilirim." ifadesine katılımcıların, \%3,4'ü $(n=15)$ kesinlikle katılmıyorum, \%9,0'u ( $n=39)$ katılmıyorum, \%25,5'i ( $n=111)$ ne katılıyorum ne katılmıyorum, $\% 52,4$ 'ü ( $n=228)$ katılıyorum, \%9,7'si ( $n=42)$ kesinlikle katılıyorum yanıtını vermiştir. Katılımcıların, "Önem verdiğim bir sosyal amacı desteklemek için marka tercihimi değiştirebilirim." ifadesine yüksek düzeyde katıldıkları saptanmıştır. Bu veriden hareketle katılımcıların, sosyal sorumluluk kampanyasına destek olan markalar ile sağlam bir bağ kurduğunu söyleyebiliriz.

"26- Sosyal sorumluluk kampanyası yürüten bir markayı satın aldığımda, kampanyaya destek verdiğim için mutlu olurum." ifadesine katılımcıların, \% 0,7 'si $(n=3)$ kesinlikle katılmıyorum, \%4,8'i $(n=21)$ katımıyorum, \%17,2'si $(n=75)$ ne katılıyorum ne katımıyorum, \%53,1'i $(n=231)$ katılıyorum, \%24,1'i $(n=105)$ kesinlikle katılıyorum yanıtını vermiştir.

“27- Markanın sosyal sorumluluk kampanyası yürütmesini samimi buluyorum" ifadesine İstanbul'da yaşayan katılımcıların, \%9,7'si $(n=42)$ kesinlikle katılmıyorum, \%13,1'i ( $n=57)$ katılmıyorum, \%28,3'ü ( $n=123)$ ne katılıyorum ne katılmıyorum, \%42,1'i ( $n=183)$ katılıyorum, \%6,9'u $(n=30)$ kesinlikle katılıyorum yanıtını vermiştir.

"28- Kullandığım markanın çevreye zarar verdiğini öğrenirsem o markayı satın almayı bırakırım." ifadesine istanbul'da yaşayan katılımcıların, \%0,7'si $(n=3)$ kesinlikle katımıyorum, \%10,3'ü $(n=45)$ katılmıyorum, \%25,5'i $(n=111)$ ne katılıyorum ne katılmıyorum, \%31,7'si ( $n=138)$ katılıyorum, \%31,7'si ( $n=138)$ kesinlikle katılıyorum yanıtını vermiştir. 


\section{3. Ölçeklere Ait Ortalama ve Standart Sapma Değerleri}

Tablo 2. Sosyal Sorumluluk Projesi Yürüten Markaya Yönelik Tutum Düzeyleri

\begin{tabular}{|l|l|l|l|l|l|}
\hline & N & Ort & Ss & Min. & Max. \\
\hline $\begin{array}{l}\text { Sosyal Sorumluluk Projesi Yürüten Markaya } \\
\text { Yönelik Tutum }\end{array}$ & 435 & 3,505 & 0,946 & 1,000 & 5,000 \\
\hline
\end{tabular}

Ankete katılanların sosyal sorumluluk projesi yürüten markalara yönelik tutum düzeyi ortalaması görülmektedir.

\section{Sosyal Sorumluluk Projesi Yürüten Markaya Yönelik Tutum ile Demografik Özellikler Arasındaki Fark}

Tablo 3. Katılımcıların Sosyal Sorumluluk Projesi Yürüten Markaya Yönelik Tutumları Ile Cinsiyetleri Arasındaki Fark

\begin{tabular}{|l|l|l|l|l|l|l|l|l|}
\hline \multicolumn{9}{|l|}{ Kadın } \\
\hline Adet & Ortalama & $\begin{array}{l}\text { Std. } \\
\text { Sapma }\end{array}$ & Adet & Ortalama & $\begin{array}{l}\text { Std. } \\
\text { Sapma }\end{array}$ & $\begin{array}{l}\text { t testi } \\
\text { sonucu }\end{array}$ & Kisıt (df) & Olasılık \\
\hline 210 & 3,5526 &, 50986 & 225 & 3,4612 &, 72251 & $-1,532$ & 403,641 &, 126 \\
\hline
\end{tabular}

Katılımcıların sosyal sorumluluk projesi yürüten markalara yönelik tutum puanı ortalamalarının cinsiyet durum değişkenine göre anlamlı bir farklılık gösterip göstermediğini belirlemek amacıyla yapılan t-testi sonucunda grup ortalamaları arasındaki fark istatistiksel açıdan anlamlı bulunmamıştır. Bu sebeple tüketicilerin cinsiyet durumları ile sosyal sorumluluk projesi yöneten markalara yönelik tutumları arasında fark yoktur ve Hipotez:1 reddedilmiştir.

Tablo 4. Katılımcıların Sosyal Sorumluluk Projesi Yürüten Markaya Yönelik Tutumları Ile Yaşları Arasındaki Farkı

\begin{tabular}{|c|c|c|c|c|c|}
\hline & Adet & Ortalama & Standart Sapma & $\mathrm{F}$ & $p$ \\
\hline $15-20$ yaş & 114 & 3,6089 & 60201 & \multirow{7}{*}{7,506} & \multirow{7}{*}{0,000} \\
\hline $21-26$ yaş & 168 & 3,3174 & ,67964 & & \\
\hline $27-32$ yaş & 81 & 3,5724 &, 52876 & & \\
\hline 33-38 yaş & 30 & 3,4500 & ,40433 & & \\
\hline 39-45 yaş & 12 & 3,7955 & ,65827 & & \\
\hline 46 ve üzeri yaş & 30 & 3,9227 &, 53678 & & \\
\hline Total & 435 & 3,5053 & ,62985 & & \\
\hline
\end{tabular}


Araştırmaya katılan katılımcıların sosyal sorumluluk projesi yürüten markalara yönelik tutum puanı ortalamalarının yaş grubu değişkenine göre anlamlı bir farklılık gösterip göstermediğini belirlemek amacıyla yapılan tek yönlü varyans analizi (Anova) sonucunda grup ortalamaları arasındaki fark istatistiksel açıdan anlamlı bulunmuştur. Tüketicilerin yaşları ile sosyal sorumluluk projesi yürüten markalara yönelik tutumları arasında fark olduğu için Hipotez:2 kabul edilmiştir. Yaş grubu 46 ve üzeri olan katılımcıların sosyal sorumluluk projelerine sahip markalara olan tutum puanı $(3,922 \pm 0,536)$, yaş grubu $21-26$ olan katılımcıların tutum puanından $(3,317 \pm 0,679)$ yüksek bulunmuştur. Yaş grubu 46 yaş ve üzeri olan katılımcıların sosyal sorumluluk projelerine sahip markalara yönelik tutum puanı $(3,922 \pm 0,536)$, yaş grubu $33-38$ olan katılımcıların tutum puanından $(3,450$ $\pm 0,404$ ) yüksek bulunmuştur.

Tablo 5. Katılımcıların Sosyal Sorumluluk Projesi Yürüten Markaya Yönelik Tutumları Ile Eğitim Durumları Arasındaki Fark

\begin{tabular}{|c|c|c|c|c|c|}
\hline & Adet & Ortalama & Standart Sapma & $\mathrm{F}$ & $p$ \\
\hline İlköğretim & 30 & 3,9000 & , 46037 & \multirow{6}{*}{7,358} & \multirow{6}{*}{0,000} \\
\hline Lise & 219 & 3,5560 &., 54245 & & \\
\hline Ön Lisans & 21 & 3,3896 & ,54651 & & \\
\hline Lisans & 78 & 3,2395 & ,89456 & & \\
\hline Lisansüstü & 87 & 3,5078 &, 52003 & & \\
\hline Total & 435 & 3,5053 & ,62985 & & \\
\hline
\end{tabular}

Ankete katılan katılımcıların sosyal sorumluluk projesi yürüten markaya yönelik tutum puanı ortalamalarının eğitim durumu değişkenine göre anlamlı bir farklılık gösterip göstermediğini belirlemek amacıyla yapılan tek yönlü varyans analizi (Anova) sonucunda grup ortalamaları arasında istatistiksel açıdan anlamlı bir fark bulunmuştur. Bu sebeple Hipotez:3 kabul edilmiştir. Eğitim durumu ilköğretim olan katılımcıların sosyal sorumluluk projelerine sahip markalara olan tutum puanı $(3,900 \pm 0,460)$, eğitim durumu lisans olan katılımcıların tutum puanından $(3,239 \pm 0,894)$ yüksek bulunmuştur. Katıımcılardan eğitim durumu ilköğretim olanların sosyal sorumluluk projelerine sahip markalara olan tutum puanı $(3,900 \pm 0,460)$, eğitim durumu ön lisans olan katılımcıların tutum puanından $(3,389 \pm 0,546)$ yüksek bulunmuştur. 
Tablo 6. Katılımcıların Sosyal Sorumluluk Projesi Yürüten Markaya Yönelik Tutumları Ille Medeni Durumları Arasındaki Fark

\begin{tabular}{|l|l|l|l|l|l|l|l|l|}
\hline \multicolumn{2}{|l|}{ Evli } & \multicolumn{3}{l|}{ Bekar } \\
\hline Adet & Ortalama & $\begin{array}{l}\text { Std. } \\
\text { Sapma }\end{array}$ & Adet & Ortalama & $\begin{array}{l}\text { Std. } \\
\text { Sapma }\end{array}$ & $\begin{array}{l}\text { t testi } \\
\text { sonucu }\end{array}$ & Kisıt (df) & Olasılık \\
\hline 93 & 3,6848 &, 47251 & 342 & 3,4565 &, 65841 & 3,129 & 433 &, 002 \\
\hline
\end{tabular}

Katıımcıların sosyal sorumluluk projesi yürüten markalara yönelik tutum puanı ortalamalarının medeni durum değişkenine göre anlamlı bir farklılık gösterip göstermediğini belirlemek amacıyla yapılan t-testi sonucunda grup ortalamaları arasındaki fark istatistiksel açıdan anlamlı bulunmuştur. Bu sebeple tüketicilerin medeni durumları ile sosyal sorumluluk projesi yöneten markalara yönelik tutumları arasında fark vardır ve Hipotez:4 kabul edilmiştir. Araştırmaya katılan evli katılımcıların sosyal sorumluluk projesi yürüten markalara yönelik tutum puanı $(x=3,684)$, araştırmaya katılan bekar katılımcıların sosyal sorumluluk projesi yürüten markalara yönelik tutum puanından $(x=3,456)$ yüksek bulunmuştur.

Tablo 7. Katılımcıların Sosyal Sorumluluk Projesi Yürüten Markaya Yönelik Tutumları Ille Çalışma Durumları Arasındaki Fark

\begin{tabular}{|l|l|l|l|l|l|l|l|l|}
\hline \multicolumn{2}{|l|}{ Aktif } & \multicolumn{5}{l|}{ Aktif Değil } \\
\hline Adet & Ortalama & $\begin{array}{l}\text { Std. } \\
\text { Sapma }\end{array}$ & Adet & Ortalama & $\begin{array}{l}\text { Std. } \\
\text { Sapma }\end{array}$ & $\begin{array}{l}\text { t testi } \\
\text { sonucu }\end{array}$ & Kısıt (df) & Olasılık \\
\hline 228 & 3,4749 &, 58834 & 207 & 3,5389 &, 67245 & $-1,058$ & 433 &, 290 \\
\hline
\end{tabular}

Katılımcıların sosyal sorumluluk projesi yürüten markalara yönelik tutum puanı ortalamalarının çalışma durum değişkenine göre anlamlı bir farklılık gösterip göstermediğini belirlemek amacıyla yapılan t-testi sonucunda grup ortalamaları arasındaki fark istatistiksel açıdan anlamlı bulunmamıştır. Bu sebeple tüketicilerin aktif iş yaşamında bulunma durumları ile sosyal sorumluluk projesi yöneten markalara yönelik tutumları arasında fark yoktur ve Hipotez:5 reddedilmiştir. 
Tablo 8. Katılımcıların Sosyal Sorumluluk Projesi Yürüten Markaya Yönelik Tutumları Ile Gelir Durumları Arasındaki Fark

\begin{tabular}{|c|c|c|c|c|c|}
\hline & Adet & Ortalama & Standart Sapma & $\mathrm{F}$ & $p$ \\
\hline 1.000 TL'den az & 201 & 3,4518 & 63994 & \multirow{5}{*}{5,072} & \multirow{5}{*}{,002 } \\
\hline 1.000-2.999 TL & 120 & 3,5932 & ,62067 & & \\
\hline 3.000-4.999TL & 87 & 3,3981 &, 59738 & & \\
\hline $\begin{array}{l}5.000 \text { TL ve } \\
\text { üzeri }\end{array}$ & 27 & 3,8586 &, 55000 & & \\
\hline Total & 435 & 3,5053 & ,62985 & & \\
\hline
\end{tabular}

Ankete katılan katılımcıların sosyal sorumluluk projesi yürüten markaya yönelik tutum puanı ortalamalarının gelir durumu değişkenine göre anlamlı bir farklılık gösterip göstermediğini belirlemek amacıyla yapılan tek yönlü varyans analizi (Anova) sonucunda grup ortalamaları arasındaki fark istatistiksel açıdan anlamlı bulunmuştur. Katılımcıların gelir durumu ile sosyal sorumluluk projesi yürüten markaya yönelik tutumları arasında anlamlı bir fark vardır hipotezi kabul edilmiştir. Bu sebeple Hipotez:6 kabul edilmiştir. Gelir durumu 5.000 TL ve üzeri olan katılımcıların sosyal sorumluluk projelerine sahip markalara olan tutum puanı $(3,858 \pm 0,550)$, gelir durumu 3.000-4.999 TL olan katılımcıların tutum puanından $(3,398 \pm 0,597)$ yüksek bulunmuştur. Katılımcılardan gelir durumu 5.000 TL ve üzeri olanların sosyal sorumluluk projelerine sahip markalara olan tutum puanı $(3,858 \pm 0,550)$, gelir durumu 1.000 TL'den az olan katılımcıların tutum puanından $(3,451 \pm 0,639)$ yüksek bulunmuştur.

\section{Sonuç}

Toplumsal konulara duyarlılı̆ın arttığı ve topluma yararlı olma görüşünün ivme kazandığı günümüzde, tüketici markalardan da benzer sorumluluklar yüklenmesini istemektedir. Diğer bir deyişle, tüketicideki toplumsal konulara olan hassasiyet, markaları da duyarlı olmaya zorlamıştır. Bu bağlamda yapılan çalışmalar, markaların sosyal sorumluluk çalışmalarına yönelmelerinin tüketicinin üzerinde olumlu etkiler yarattığını göstermektedir. Bu doğrultuda, çevreye, topluma, çalışanlarına ve tüketiciye karşı sorumluluğu olan markalar, rakiplerinden ayrışmak, tüketicide olumlu duygular oluşturmak, marka imajını güçlendirmek için sosyal sorumluluk projelerine yönelmektedir. Yapılan literatür çalışmaları sosyal sorumluluk projesi yürüten markaların imajlarını güçlendirdiği, satın almayı gerçekleştirdiği, sadakati arttırdığı ve olumlu tutum oluşturduğu bilgisini desteklemektedir. Bu çalışmada tüketicinin sosyal sorumluluk projesi yürüten markalara olan tutumlarında demografik özelliklerinin rolünün saptanmasını amaçlanmıştır. Araştırmada zaman ve mali kısıtlardan dolayı sadece İstanbul ilindeki Asya ve Avrupa kıtalarındaki iki A101 marketini ziyaret eden kadın ve 
erkek tüketicilerden elde edilen veriler analiz edilmiştir. Yapılan araştırmada, tüketicinin cinsiyeti, yaşı, eğitim durumu, medeni durumu, aktif çalışma durumu ve gelir durumu ile sosyal sorumluluk projeleri geliştiren markalara yönelik tutumları arasında fark olup olmadığı irdelenmek için 435 kişiye yüz yüze anket uygulanmıştır

Çalışmada, katılımcıların sosyal sorumluluk projesi yürüten markalara yönelik tutum puanı ortalamalarının cinsiyet durum değişkenine göre anlamlı bir farklııık gösterip göstermediğini belirlemek amacıyla t-testi yapılmıştır. Bu testin sonucunda grup ortalamaları arasındaki fark istatistiksel açıdan anlamlı bulunmamıştır. Diğer bir değişle, tüketicilerin cinsiyet durumları ile sosyal sorumluluk projesi yöneten markalara yönelik tutumları arasında fark yoktur. Bu sebeple, Hipotez:1 reddedilmiştir. Tüketicinin diğer demografik özelliklerden olan yaş grubu değişkenine göre anlamlı bir farklılık gösterip göstermediğini belirlemek amacıyla yapılan tek yönlü varyans analizi (Anova) sonucunda ise grup ortalamaları arasındaki fark istatistiksel açıdan anlamlı bulunmuştur. Tüketicilerin yaşları ile sosyal sorumluluk projesi yürüten markalara yönelik tutumları arasında fark olduğu için Hipotez:2 kabul edilmiştir. Katılımcılardan 46 ve üzeri yaş grubundakilerin sosyal sorumluluk projelerine sahip markalara olan tutum puanı $(3,922 \pm 0,536)$, yaș grubu $21-26$ olanların tutum puanlarına göre $(3,317 \pm$ 0,679 ) yüksek bulunmuştur. Ayrıca yaş grubu 46 yaş ve üzeri olan katılımcıların sosyal sorumluluk projelerine sahip markalara yönelik tutum puanı $(3,922 \pm$ $0,536), 33-38$ yaş grubunda olan katıımcıların tutum puanından $(3,450 \pm 0,404)$ yüksektir. Sonuç olarak, tüketicilerin yaşları ile sosyal sorumluluk projesi yürüten markalara yönelik tutumları arasında farklılık bulunmaktadır. Ayrıca katılımcıların sosyal sorumluluk projesi yürüten markaya yönelik tutum puanı ortalamalarının eğitim durumu değişkenine göre anlamlı bir farklılık gösterip göstermediğini belirlemek amacıyla yapılan tek yönlü varyans analizi (Anova) sonucunda ise grup ortalamaları arasındaki fark anlamlı bulunmuştur. Bu sebeple Hipotez:3 kabul edilmiştir. Katılımcılarda eğitim durumu ilköğretim olanların sosyal sorumluluk projelerine sahip markalara olan tutum puanı $(3,900 \pm 0,460)$ iken, eğitim durumu lisans olan katılımcıların tutum puanı $(3,239 \pm 0,894)$ 'dır. Yani eğitim durumları ilköğretim olanların tutum puanı, eğitim durumu lisans olanların tutum puanından yüksek bulunmuştur. Ayrıca eğitim durumu ilköğretim olan katıımcıların sosyal sorumluluk projelerine sahip markalara olan tutum puanı $(3,900 \pm 0,460)$, eğitim durumu ön lisans olan katıımcıların tutum puanından $(3,389 \pm 0,546)$ yüksektir. Katılımcıların sosyal sorumluluk projesi yürüten markalara yönelik tutum puanı ortalamalarının medeni durum değişkenine göre anlamlı bir farklılık gösterip göstermediğini belirlemek amacıyla yapılan t-testi sonucunda grup ortalamaları arasındaki fark istatistiksel açıdan anlamlı bulunmuştur. Araştırmaya katılan evli katıımcıların sosyal sorumluluk projesi yürüten markalara yönelik tutum puanı $(x=3,684)$, araştırmaya katılan bekar katılımcıların sosyal sorumluluk projesi yürüten markalara yönelik tutum puanından $(x=3,456)$ yüksek bulunmuştur. Tüketicilerin medeni durumları ile sosyal sorumluluk projesi yöneten markalara yönelik tutumları arasında fark bulunduğu sonucuna varılmış ve hipotez 4 kabul 
edilmiştir. Katılımcıların sosyal sorumluluk projesi yürüten markalara yönelik tutum puanı ortalamalarının çalışma durum değişkenine göre anlamlı bir farklılık gösterip göstermediğini belirlemek amacıyla yapılan t-testi sonucunda grup ortalamaları arasındaki fark istatistiksel açıdan anlamlı bulunmamıştır. Bu sebeple tüketicilerin aktif iş yaşamında bulunma durumları ile sosyal sorumluluk projesi yöneten markalara yönelik tutumları arasında fark yoktur. Bu sebeple araştırmadaki Hipotez 5'de reddedilmiş̦ir. Son bir demografik özellik olarak gelir durumuna bakılmıştır ve ankete katılan katılımcıların sosyal sorumluluk projesi yürüten markaya yönelik tutum puanı ortalamalarının gelir durumu değişkenine göre anlamlı bir farklılık gösterip göstermediğini belirlemek amacıyla yapılan tek yönlü varyans analizi (Anova) sonucunda grup ortalamaları arasındaki fark istatistiksel açıdan anlamlı bulunmuştur. Yapılan araştırmaya göre, gelir durumu 5.000 TL ve üzeri olan katılımcıların sosyal sorumluluk projelerine sahip markalara olan tutum puanı $(3,858 \pm 0,550)$, gelir durumu 3.000-4.999 TL olan katılımcıların tutum puanından $(3,398 \pm 0,597)$ yüksektir. Gelir durumu $5.000 \mathrm{TL}$ ve üzeri olan katılımcıların sosyal sorumluluk projelerine sahip markalara olan tutum puanı $(3,858 \pm 0,550)$, gelir durumu $1.000 \mathrm{TL}$ 'den az olan katılımcıların tutum puanından $(3,451 \pm 0,639)$ yüksek bulunmuştur. Elde edilen bulgular doğrultusunda katıımcıların gelir durumu ile sosyal sorumluluk projesi yürüten markaya yönelik tutumları arasında anlamlı bir fark vardır hipotezi kabul edilmiştir. Bu sebeple Hipotez:6 kabul edilmiştir. Katıımcıların demografik özellikleri ile sosyal sorumluluk projesi yürüten markalara olan tutumları arasında anlamlı bir farkın olup olmadığının araştııılığı bu çalışmanın, markaların stratejilerini belirlemesinde yol gösterici olacağı düşünülmektedir. Ayrıca çalışma ileride yapılacak daha kapsamlı araştırmalara da yol gösterici olabilir.

\section{Kaynakça}

Aktan, C. C. ve Börü, D. (2007). Kurumsal Sosyal Sorumluluk. İstanbul: IGiAD Yayınları.

Alexander, A., Francis, A., Kyire, L. A. ve Mohammed, H. (2014). The Effect Of Corporate Social Responsibility On Brand Building. International Journal of Marketing Studies, 6(3), 126-113. http://dx.doi.org/10.5539/ijms.v6n3p126

Alnıaçık, Ü. (2009). Tüketicilerin Çevreye Duyarıı̆ı̆ı ve Reklamlardaki Çevreci İddialar. Kocaeli Üniversitesi Sosyal Bilimler Enstitüsü Dergisi, (18) / 2, 48-79.

Arendt, S. ve Brettel, M. (2010). Understanding The Influence of Corporate Social Responsibility on Corporate Identity, Image and Firm Performance, Management Decision. 48(10), 1469-1492.

Argüden, Y. (2002). Kurumsal Sosyal Sorumluluk. İstanbul: Ar-Ge Danışmanlık Yayınları No:3.

Aydın, B. (2013). Kurumsal Sosyal Sorumluluk Faaliyetlerinin Müşteri Bağlılığına Etkisi: Yiyecek içecek Sektöründe Bir Uygulama. Yayınlanmamış yüksek lisans tezi, Anadolu Üniversitesi. 
Bayraktaroğlu, G., B. İlter ve Tanyeri, M. (2009). Kurumsal Sosyal Sorumluluk: Pazarlamada Yeni Bir Paradigmaya Doğru (1. baskı). İstanbul: Literatür Yayınları.

Becan, C. (2011). Kurumsal Sosyal Sorumluluk Kavramının Paydaş Teorisi ve İletişim Yaklaşımı Açııından Değerlendirilmesi: Bankaların Basın Bültenlerine Yönelik Bir İçerik Analizi. Selçuk Iletişim Dergisi , 7 (1), 16-35.

Becker-Olsen, K. L., ve Hill, R. (2006). The Impact Of Sponsor Fit On Brand Equity. Journal of Service Research, 9(1), 73-83. http://dx.doi. org/10.1177/1094670506289532

Carroll, A.B., (1991). The Pyramid of Corporate Social Responsibility: Toward the Moral Management of Organizational Stakeholders. Business Horizons.

Castaldo, S., Perrini, F., Misani, N. ve Tencati, A. (2009). The Missing Link Between Corporate Social Responsibility and Consumer Trust: The Case of Fair Trade Products. Journal of Business Ethics. 84,1-15.

Chernev, A., ve Blair, S. (2015). Doing Well by Doing Good: The Benevolent Halo of Corporate Social Responsibility. Journal Of Consumer Research, 41(6), 14121425.

Çerik, Ş. ve Özarslan, E. (2008). Çalışanların Sosyal Sorumluluk Boyutlarına İlişkin Algılamaları: İlaç Sektöründe Karşılaştırmalı Bir Uygulama. Ege Akademik Bakış. 8(2), 587-604.

Dean, D.H. (2013). Consumer Perception of Corporate Donations Effects of Company Reputation for Social Responsibility and Type of Donation. Journal of Advertising. 32(4), 91-102.

Elden, M. (2013). Reklam ve Reklamcılık (2. Baskı). İstanbul: Say Yayınları.

Elkinton, J. (1998). Cannibals with Forks: The Triple Bottom Line of 21st Century Business. (2nd ed). Oxford: Capstone Publishing Ltd.

Frederick, W. C. (1960). The Growing Concern Over Business Responsibility. California Management Review, 2, 54-61.

Gegez, A.E. (2007). Pazar Araştırmaları. İstanbul: Beta Yayınevi

Giannarakis, G., ve Theotokas, I. (2011). The Effect Of Financial Crisis In Corporate Social Responsibility Performance. International Journal of Marketing Studies, 3(1), 2-10. http://dx.doi.org/10.5539/ijms.v3n1p2

Gilbert, F. W., ve Warren, W. E. (1995). Psychographic Constructs And Demographic Segments. Psychology \& Marketing, 12, 223-237.

Gibson, B. (2008). Can Evaluative Conditioning Change Attitudes Toward Mature Brands? New Evidence from the Implicit Association Test. Journal of Consumer Research, 35, 178-188.

Gürak, A. (2017). Kids Marketing ve Sosyal Sorumluluk. Marketing Türkiye. Erişim 18 Aralık 2017, https://www.marketingturkiye.com.tr/koseyazilari/kidsmarketing-ve-sosyal-sorumluluk/ 
Herbert C.M. ve Von Schantz, C. (2007). Communicating Corporate Social Responsibility-Brand Management. Electronic Journal of Business Ethics and Organization Studies. 12, (2).

Hoeffler, S., Bloom, P.N. ve Kelller, K.L., (2010). Understanding Stakeholder Responses To Corporate Citizenship Initiatives: Managerial Guidelines And Research Directions. Journal Of Public Policy And Marketing, 29(1), 78-88.

Huynh, E. ve Friberg, M. (2014). Creating a Socially Responsible Brand Attitude: Influences on Consumer Brand Attitude in CSR-related Contexts. Bachelor Thesis in Marketing, Stockholm School of Economics.

Inceoğlu, M. (2011). Tutum Algı İletişim (6.baskı). Ankara: Siyasal Kitabevi.

Inncesu, Ç. D. (2011). Türkiye'deki Sosyal Sorumluluk Projelerinin Marka Farkındalığı Üzerindeki Etkileri. Yayınlanmamış yüksek lisans tezi, Haliç Üniversitesi.

Jasina, T.K. (2014). Consumer Behaviour Models: An Overview. Sai Om Journal of Commerce \& Management. 1 (5), 34-43.

Kakabadse, N., Rozuel, C. ve Lee-Davıes, L. (2005). Corporate Social Responsibility and Stakeholder Approach: A Conceptual Review, International Journal Business Governance and Ethics. 4(1), 277-302.

Kaşlı, T.E. (2011). Kurumsal Sosyal Sorumluluk Faaliyetlerinin Marka Imajı ve Marka Farkındalığına Etkileri: Iş̧letme Öğrencilerine Yönelik Bir Uygulama. Yüksek lisans tezi, Yıldız Teknik Üniversitesi Sosyal Bilimler Enstitüsü.

Keller, K.L. (1993). Conceptualizing, Measuring and Managing Customer-Based Brand Equity. Journal of Marketing 57(1), 1-22.

Kim, C. H., ve Scullion, H. (2013). The Effect Of Corporate Social Responsibility (CSR) On Employee Motivation: A Cross-National Study. The Poznan University of Economics Review , 13 (2), 5-25.

Kurtuluş, K. (2010). Araştırma Yöntemleri. Yayın No: 351. İstanbul: Türkmen Kitabevi.

Kotler, P. ve Lee, M. (2013). Kurumsal Sosyal Sorumluluk. (S. Kaçamak, Çev.). İstanbul: MediaCat Yayınları.

Lai, C. S., Chiu, C. J., Yang, C. F., ve Pai, D. C. (2010). The Effects Of Corporate Social Responsibility On Brand Performance: The Mediating Effect Of Industrial Brand Equity And Corporate Reputation. Journal Of Business Ethics, 95(3), 457469.

Laleli, Ş. (2015). Perakende Sektöründe Neler Oluyor? . Fortune Turkey. Erişim 27 Nisan 2017.http://www.fortuneturkey.com/perakende-sektorunde-neleroluyor-12993

Lembet, Z. (2012). Markalar ve Kurumsal Sosyal Sorumluluk. Hacettepe Sosyal Bilimler Dergisi. Erişim 13 Nisan 2016. http://www.sdergi.hacettepe.edu.tr/ makaleler/MARKALARVEKURUMSALSOSYALSORUMLULUK.pdf 
Lii Yuan-Shuh ve Lee, M. (2012). Doing Right Leads to Doing Well: When The Type of CSR and Reputation Interact to Affect Consumer Evaluations of The Firm. Journal Business Ethics. 105,69-81.

Loken, B., Joiner, C. ve Peck, J. (2002). Category Attitude Measures. Journal of Consumer Psychology, 12 (2), 149-161.

Mainieri T., Barnett, E. G., Valdero, T. R., Unipan, J. B. ve Oskamp, S. (1997). Green Buying: The Influence of Environmental Concern on Consumer Behavior. The Journal of Social Psychology, 137(2), 189-204, DOI: 10.1080/00224549709595430

Maignan, I. (2001). Consumers' Perceptions of Corporate Social Responsibilities: A Cross-Cultural Comparison. Journal of Business Ethics, 30, 57-72.

Prado-Lorenzo J.M., Gallego-Álvarez,I., García-Sánchez, I. M., Domínguez, L.R. (2008). Social responsibility in Spain: Practices and Motivations in Firms., Management Decision, 46(8),1247-1271. https://doi. org/10.1108/00251740810901417

Onaran, B., Uyar, A. ve Avan, A. (2013). Eğitim Destekli Kurumsal Sosyal Sorumluluk Kampanyalarına Yönelik Tüketici Algılamaları. Business and Economics Research Journal., 4 (3), 131-157.

Özdemir, H. (2009). Kurumsal Sosyal Sorumluluğun Marka İmajına Etkisi. İstanbul Ticaret Üniversitesi Sosyal Bilimler Dergisi, 8 (15), 57-72.

Özdamar, K. (2004). Paket Programlar ile İstatiksel Veri Analizi. (5.Baskı). Eskişehir: Kaan Kitabevi.

Özgüven, N. (2010). İşletmelerin Uyguladıkları Sosyal Sorumluluk Kampanyalarının Müşteri Bağlıı̆ı Yaratmaktaki Rolü Ve Bir Uygulama. Yayınlanmamış doktora tezi, Dokuz Eylül Üniversitesi.

Park, C.W., Maclnnis, D. J., Priester, J., Eisingerich, A.B., ve Lacobucci, D. (2010). Brand Attachment and Brand Attitude Strength: Conceptual and Empirical Differentiation of Two Critical Brand Equity Drivers. Journal of Marketing, 74, 1-17.

Peracchio, L. A. ve Meyers-Levy, J. (1997). Evaluating Persuasion-Enhancing Techiques from a Resource-Matching Perspective. Journal of Consumer Research, 24 (2), 178-91.

Putrevu, S. ve Kenneth R. L. (1994). Comparative and Noncomparative Advertising: Attitudinal Effects Under Cognitive and Affective Involvement Conditions. Journal of Advertising, 23 (2), 77-91.

Polonsky. M.J. ve Jevons.,C. (2006). Understanding Issue Complexity When Building a Socially Responsible Brand. European Business Review, 18(5), 340349.

Quazi, A. M. ve O'Brien, D. (2000). An Empirical Test Of A Cross-National Model Of Corporate Social Responsibility. Journal of Business Ethics. 25, 33-51. 
Slama, M. E., ve Tashlian, A. (1985). Selected Socioeconomic And Demographic Characteristics Associated With Purchasing Involvement. Journal of Marketing, 49, 72-82.

Sönmez, B. (2014). Sosyal Sorumluluk Projelerinin Işletme Imajina Etkisi: Yerli Turistler Üzerinde Bir Araştırma. Yayınlanmamış yüksek lisans tezi, Balıkesir Üniversitesi.

Straughan R.D. ve Roberts, J. A. (1999). Environmental Segmentation Alternatives: A Look At Green Consumer Behavior In The New Millennium, Journal of Consumer Marketing, 16(6), 558-575, https://doi.org/10.1108/07363769910297506

Sujan, M ve Bettman, J.R. (1990). The Effects of Brand Positionin Strategies on Consumers, Journal of Marketing Research, 4 (3), 54-67.

Tandoğan, G.K. (2009). Otel Markalarının Konumlandırılmasında Sosyal Sorumluluk Kampanyalarının Etkisi. Yayınlanmamış doktora tezi, Dokuz Eylül Üniversitesi Sosyal Bilimler Enstitüsü.

Tosun, N. (2017). Marka Yönetimi (3.Baskı). İstanbul: Beta Yayıncılık.

Uslu, A., Başçı, A. ve Gambarov, V. (2008). Türkiye'de Tüketicilerin Sosyal Sorumluluk Kampanyalarına ve Sosyal Açıdan Sorumlu Şirketlere Karşı Tutumu. İşletmecilikte Yeni Gelişmeler ve Fırsatlar: Muhan Soysal İşletmecilik Konferansı Kitabı. Kuzey Kıbrıs: ODTÜ, 3-6 Eylül.

Wesley, S.C., Lee, M. ve Kim, E.Y. (2012). The Role of Perceived Consumer Effectiveness and Motivational Attitude on Socially Responsible Purchasing Behavior in South Korea. Journal of Global Marketing, 25,29-44.

Wu, S. (2003). The Relationship Between Consumer Characteristics And Attitude Toward Online Shopping. Marketing Intelligence \& Planning, 21 (1), 37-44. https:// doi.org/10.1108/02634500310458135

Wu, S. ve Wang, W.H. (2014). Impact of CSR Perception on Brand Image, Brand Attitude and Buying Willingness: A Study of a Global Cafe. International Journal of Marketing Studies. 6 (6), 43-56.

Wood D. (1991). Corporate Social Performance Revisited. The Academy of Management Review 16(4), 691-717.

Yalur, E. (2014). Türkiye'deki Sosyal Sorumluluk Kampanyalarının Reklam Grafiği Açısından Değerlendirilmesi. Yayınlanmamış yüksek lisans tezi, İstanbul Arel Üniversitesi.

Zincir Markerlerin Nisan AçIlışları. (10 Mayıs 2016). Erişim 26 Temmuz 2016. http:// www.ortakalan.com.tr/haberler/zincir-marketlerin-nisan-acilislari-22459\#1\%20 http://www.ortakalan.com.tr/haberler/zincir-marketlerin-nisan-acilislari-22459\#1 
